\title{
Decolonizing Vocational Education in Togo: Postcolonial, Deweyan, and Feminist Considerations
}

\author{
Tairou Goura and Deborah L. Seltzer-Kelly
}

\begin{abstract}
The Republic of Togo, like many African former colonies, has struggled to create a system of vocational education that will aid its efforts to move beyond the status of a satellite to Western economies. We incorporate postcolonial, Deweyan and feminist perspectives to understand how lingering colonialism and neo-colonial forces have hampered reform efforts in one postsecondary vocational program, and have posed a special challenge to the women who comprise the majority of its students. We argue that deeper attention to Deweyan principles for critical thought, in conjunction with consideration for local settings, is vital to meaningful and democratizing reform
\end{abstract}

In his landmark work, Democracy and Education, John Dewey (1916/1980) proposed that "democracy is more than a form of government; it is primarily a mode of associated living, of conjoint communicated experience" (93). Given this, he argued, the role of the system of public education in a democracy must not only facilitate individual development, but do so in a way that simultaneously attends to the larger social good. Preparation for vocation was central to this effort, understood not as narrow technical training, but rather as "such a direction of life activities as renders them perceptibly significant to a person, because of the consequences they accomplish, and also useful to his associates" (316). The threat to that vision lay in a system of vocational education that, rather than serving as a means of preparation for freedom, growth, and social cooperation, instead became "an agency for transferring the older division of labor and leisure, culture and service, mind and body, directed and directive class, into a society nominally democratic" (328).

Development of a system of education that will facilitate democratic life and economic self-sufficiency, rather than one that will perpetuate older systems of dependence and inequity, is a challenge faced by many African nations that now function as satellites to the Western economic system. This project is made more difficult by the fact that these efforts must be carried out in the presence of former colonial masters, "who now wear the gowns of neo-colonialism and globalisation" (Dube 1999, 10). The United Nations Educational, Scientific and Cultural Organization 
(UNESCO) is focused upon supporting these processes, and has made Vocational Education and Training (VET) a funding priority within its Millennium Development Goals. However, critiques of its vocational efforts thus far in Africa point toward continuing problems, ranging from the kind of excessively narrow focus decried by Dewey and other educational philosophers, to inadequate and inferior curricula, materials, and teacher preparation (McGrath 2011, 39). The situation is additionally complicated by the question of how social autonomy and economic self-sufficiency are to be accorded to women-a conundrum given traditional patriarchal attitudes combined with neoliberal authoritarian structures (Dube, 223-25).

In the essay that follows, we examine the ways in which these tensions and challenges manifest in one postsecondary vocational education program: executive secretaryship studies at the University of Lomé, in the Togolese Republic (Togo). We consider how the lingering control exercised by Togo's former colonial masters and by neo-colonial economic systems has continued to undermine Togo's efforts at democratization, and detail the effects upon the executive secretaryship program. Given that women comprise the majority of the enrollment in the executive secretaryship program, we devote particular attention to the construction of women's roles and status within Togo's current economic sphere, which reflects the broader dilemma of women in postcolonial and traditionally patriarchal societies.

The first author is a Togolese vocational educator and a former faculty member in the executive secretaryship studies program that we consider here. As a Fulbright scholar, he received a doctorate in educational administration in the United States. The second author is a US curriculum researcher and teacher educator who previously taught at at the institution hosting the first author. The present work developed from our conversations about intersections between postcolonial thought and Dewey's work-particularly his scholarship on vocational education. As we began to explore the remarkable ways in which we could see Dewey's theoretical concerns reflected in Togo's system of vocational education, we also realized that principles extracted from Dewey's thought could be employed to guide change on the scale of the first author's program. This essay is intended to retrace and share those discussions.

We pause here to address what might appear to be contradictions in our use of Dewey's scholarship. First, and perhaps most critically, it might seem an exercise in further colonization to claim a postcolonial stance while grounding much of our analysis in the thought of a scholar from a developed-and colonialist-nation such as the US. In fact, though, as we shall discuss in more detail shortly, Dewey's credentials as a critic of colonialism are well-established, if sometimes overlooked.

We are mindful also that Dewey's (1936/1987) comprehensive vision for a democratic and democratizing system of education contemplated robust integration between the vocations and the liberal arts at every age and level. He bemoaned the fact that the US had failed to attend to the needed coordination, since 
Professional schools are dependent upon what is done in the colleges; the colleges are dependent upon the product of secondary education; and the work of the latter is necessarily conditioned upon what has happened in elementary schools. One of the great problems of adult education is whether its chief business is to try to repair the defects of the regular school system or whether it can build upon and extend the inspirations received-the desires aroused by previous schooling. (176)

Our present purpose seems to fly in the face of the analysis, since we set out here to suggest that Dewey's work can provide guidance even for educational reforms of limited scope, given conditions that make large-scale restructuring impossible, at least at present. In this, we follow Sidney Hook's (1980) view that Dewey realized that substantive reform entails significant difficulties, but that "such difficulties by no means justify acceptance of the status quo and compliance with educational and industrial practices that stunt the lives of so many. Dewey was no Utopian and insisted that ideals must be practicable. It is not a case of all or nothing" (xix). We would argue, then, that Dewey would hardly wish for the students in the executive secretaryship program to have to await implementation of national educational reform at every level before they can hope for changes that will benefit themselves and their program.

Due to the paucity of published studies of Togo's educational system, as well as the near impossibility of gaining access to governmental archives and official guidelines for examinations, the descriptions of the Togolese educational programs contained in this work are drawn from the first author's personal knowledge and experience, rather than from governmental and scholarly sources. As such, this work is offered as a historic and philosophical analysis, rather than as an empirical study. We begin with an overview of the executive secretaryship studies program and its past efforts toward reform. We then take up a postcolonial lens to consider the lingering influence of France's system of public education upon Togolese schools, before turning to Dewey's scholarship both to elucidate alternative principles, and to move our analysis from the postcolonial to the critical. We examine the intensified effects of postcolonial and neo-colonial pressures upon women. Finally, we return to Dewey's work to suggest that deepened attention to local conditions, and to integration among the theoretical and abstract realms, can lead to incremental, but still significant, change.

\section{Togo's Executive Secretaryship Program: An Overview}

After 1945, given the need to rebuild economies destroyed by the Second World War, technical and vocational training schools were seen as a useful support to the enhancement of economic growth for France and her colonial possessions. As a part of France's post-war reforms to vocational education, many specialties in Togolese universities, including the program in executive secretaryship, were moved 
from secondary to the postsecondary level. Most notably, this change meant that students entering the program would previously have completed an advanced threeyear senior high school program and passed Togo's baccalaureate examination-the equivalent to the French baccalauréat général, the British A-levels, the US Advanced Placement (AP) or the International Baccalaureate (IB) examinations.

Analyzing the role of economic and social development in the evolution of cultural systems, Boutin (1983) argued that general education is concerned with the long term, while vocational training gives answers to short term and immediate needs. General education develops critical thinking, while vocational training is oriented toward task execution; its philosophy is market-driven. From this perspective, the postwar change to Togo's system of vocational education may be seen as an effort not only to meet the short-term needs of the public and private sectors for a skilled workforce for support functions, but to prepare flexible workers capable of assisting managers with longer-term planning through polyvalent skills, independent initiative-taking, and decision-making. In the case of the executive secretaryship program, the goal was to prepare individuals to work with some degree of autonomy and authority under the responsibility of a manager or administrator belonging to the upper hierarchy in a corporate setting.

Since achieving independence from France in 1960, Togo has targeted the technical and professional fields in planning for its own vocational training systems. The Togolese educational system was once reformed in 1975-a reform that promised a real contribution to a democratic society where students would be trained according to their social needs. In so doing, Togolese authorities considered vocational and technical education as a springboard for development and a strong means to ease poverty (Nyame and Nuakey 2003). However, the first author's experiences and observations indicate that the reality in the field was quite different: the reform did not fundamentally touch curricular contents in vocational education. Further, the principal teachers who led technical schools' programs in the 1980s-1990s were French co-operants. They did not change things to adapt them to Togolese realities, but continued to teach as they had done in France.

Some adjustments to the Togolese curriculum were accomplished in 1989 through copying and adapting programs from Cote d'Ivoire (The Ivory Coast), Tunisia, and France. By mixing them, Togo created a hybrid curriculum for its vocational training system. In the area of executive secretaryship, however, the approach and the goals of the original French program were largely retained. Lessons in the executive secretaryship curriculum are comprised of two groups: the principals or "dominants," and the subsidiaries. The principals are: computer science, typing, professional writing, administration skills, stenography, French, and English. The subsidiaries are: economy, accountancy, law, and statistics. During the two-year training, students' assessment activities and planning are under the responsibility of each school; there is no national guideline. 
Hands-on learning activities are required for some classes, particularly those for which specific practices are mandatory: stenography, typewriting, computer science, professional writing, and accountancy. In the majority of cases, though, individual teachers decide whether to include external activities in their courses or not. These external activities might include, for example, visits in companies for field experience. This reflects the influence of the French model of training, in which there is a separation between theoretical learning in classrooms and practical skill acquisition in the workplace through internship. It is also quite different from the German dual system, which combines theory and practice through apprenticeship. As we will consider shortly, however, attempts to transfer the German apprenticeship system to Togo have failed.

At the end of two-year trainings for postsecondary vocational programs, there is a nationwide standardized assessment, during which each candidate is assessed in his or her field of specialization. The conditions of this examination are clearly articulated in the curriculum. The national assessment is centralized under the responsibility of the National Examination and Certification Office. There are theoretical and practical activities. At the end of each nationwide assessment, there is an official school ranking according to the results (passing rates), indicating the relative success of schools in preparing their students for the examination.

Despite the five decades since Togo achieved independence, the executive secretaryship curriculum still almost completely lacks Togolese references; much of the content of the curriculum is neither useful to, nor adapted for, Togolese interests and social needs. Echoing the French focus of the baccalaureate-level education, the priorities of the vocational program continue to be based upon French standards: social, technical, professional, and economic ideologies. The criterion of knowledge is framed according to what is considered valuable for France, revealing the "copy and paste" model. Most critically, the entire system is focused upon preparing students to work in an economic system modeled along the lines of the French system-even though this is no longer appropriate in the postcolonial era.

Togo is suffering from economic challenges that are not adequately addressed by its system of vocational education. Current figures are not available, but the unemployment rate was about 22\% in 2003 (Abdallah and Amouzouvi 2007), and did not change in 2006 (Kudaya 2008). Given recent global economic trends, it seems unlikely to have improved since. While detailed data on patterns of employment for graduates of the executive secretaryship program are not available, the first author and his colleagues have observed some patterns. Economic ties to French corporations certainly continue to exist, but these fail to provide significant numbers of jobs. Regardless of their specialty, students are not actually trained for independent entrepreneurship, so must struggle to find employment in a weakened economy. Because of the great number of graduating students and the inability of the public sector to provide sufficient jobs for youth, private sector employers find it easy to 
create and to fill underpaid jobs. Economic necessity obliges some students to accept what might have been refused by previous applicants. When they find jobs, they are typically paid less compared to the official wages.

Thus, we would argue that, despite careful initial planning to match the program in executive secretaryship to the needs of the market, the current system must be considered a failure by its own standards since it does not meet the actual needs of the marketplace. An official evaluation of the curriculum was conducted in 2008, in which teachers, employers, and students complained of the weakness of the curriculum, but implementation of the new readjusted curriculum has not yet been undertaken due to lack of funding. In any case, from the postcolonial perspective we take up next, it becomes clear that merely improving the alignment between the educational system and actual economic conditions cannot satisfy the demand for a system of education that will meet the economic and social needs of all of Togo's peoples.

\section{Colonizing Minds}

As Said (1993) has shown, the inculcation of a European worldview through immersion in European classic works was central to the European system of colonial education, and was designed to prevent the emergence of an indigenous perspective. In his words, "the power to narrate, or to block other narratives from forming and emerging, is very important to culture and imperialism, and constitutes one of the main connections between them" (xiii). In the words of one $19^{\text {th }}$ century British colonial official, the intention was "to form a class who may be interpreters between us and the millions we govern; a class of persons, Indian in blood and color, but English in taste, in opinions, in morals, and in intellect"' (Spivak 1988, 282). ${ }^{1}$ The purpose of the colonial educational model, in other words, was not only to prepare select individuals from the indigenous population to facilitate the economic exploitation of the colony, but to actually instill in them the norms and expectations of the colonizer, replacing the indigenous systems of reference with those relevant to the colonial power.

The Anglophone nations of Western Africa implemented wide-ranging and systematic revisions to their curricula in the early 1960s, creating new structures for curriculum planning in the wake of independence. In the Francophone nations, by contrast, little has been accomplished toward curriculum reform, even in the wake of UNESCO-sponsored curriculum seminars in 1978 and 1982. The use of national languages for instruction in the various countries reflects the differing approaches: by 1995, the use of English as the language of instruction had been reduced considerably in Anglophone nations, while instruction in Togo still occurred in French 100\% of the time at every level of education (Obanya 1985, 320). While more recent data is lacking, there is broad consensus that little progress has been made throughout Africa since the last large-scale study of this issue in 1985 (UNESCO 2010). 
Interestingly, too, efforts to move toward instruction in indigenous languages in the Francophone nations have tended to meet resistance based upon fear that this would constitute a drop in standards, or that the indigenous languages are inadequate for scientific and technical concepts (Obanya, 323). The sense of the superiority of French language and cultural products is, as Said has observed, a notable historic characteristic of the French colonial empire, which was "uniquely connected to the French national identity, its brilliance, civilizational energy, special geographical, social, and historical developments" (171). As noted above, students entering the executive secretaryship program have been immersed for three years in the humanist environment of Togo's system of baccalaureate education, which is substantially unchanged since independence. In literature and philosophy, for example, questions on the baccalaureate exam may be drawn from the works of classic authors such as Voltaire, Rousseau, Sartre, Descartes, Hugo, Rabelais, Rimbaud, Apollinaire, Flaubert, Levi-Strauss, de Saussure, Daudet, Prevert, and de Lamartine, to name but a few.

It would be a misunderstanding of Dewey to claim that "historical tradition with its remote figures and events and its expression in a canon of literature, art and philosophy must be dismissed in the name of what is 'relevant' to the student's contemporary experience" (Alexander 1995, 76). We might certainly argue that, from a Deweyan perspective, there could be value in the inclusion of literature such as this, since: "Like Nussbaum, Dewey understands that many important facets of the human condition and human experience only divulge their full significance when expressed artistically or imaginatively in some narrative- and context-sensitive manner" (Granger 2006, 15). However, Dewey's writing reveals that, however much he valued the aesthetic, he saw little of inherent educational value in the Western literary canon; rather, its value was instrumental, to be measured in terms of the specific purpose for the inclusion of any particular work (Seltzer-Kelly et al 2010). In fact, Dewey's (1934/1981) analysis of the colonizing effect of the Western canon actually anticipated Said's concerns: he argued that older and long-validated artistic materials (including literary works), are infused with nationalist and imperialist overtones, conveying "superior cultural status" that undermines students' abilities critically engage with them on a deep and reflective level, deadening the students to real and urgent cultural and political phenomena in the surrounding world (14).

The fact that students in the executive secretaryship program receive preparation in fields such as law and economics to complement their vocational skills courses might also appear to fulfill Dewey's (1917/1980a) advocacy for "broadening the scope and deepening the spirit of professional education" (154) such that individuals taking part would become acquainted with "an adequate recognition of its human bearing and public purpose" (156). However, the Eurocentric focus of the baccalaureate curriculum continues in the executive secretaryship program, once again subverting critical understandings related to the Togolese situation. Examples can be taken from the classes in law and economics, which are exclusively related to the European con- 
text. In economics coursework, as for other two-year training programs, aspects of the curriculum are dedicated to the study of the European Union: its history, foundations, objectives, and mechanism in a world more and more globalized. Meanwhile, students are not sufficiently aware of the reality of their own political and economic environment, including those in which Togo is directly involved: the Economic Community of West African States (ECOWAS) in West Africa, the Community of Sahelo-Saharan States (CENSAD) in sub-Saharan countries, or the African Union (AU). In law courses, the materials on the judiciary system and the content of the program are grounded in the French model, based upon the writings of Montesquieu that inspired the authors of the French Constitution of 1791.

Dewey (1917/1980a) recognized that the traditional role of higher education was, at least in part, one of vocational preparation, including: "what was needed by the clerks, secretaries, scribes, etc., who have always always had a large part of the administering of governmental affairs in their hands." As he observed, though, "some portions of this original professional training ceased to be vocationally useful and then became the staple of a cultural and disciplinary education ... retained as a necessary educational ornament (as useless buttons are retained on the sleeves of men's coats)" (144-145). Certainly, the executive secretaryship program is burdened by content that might have been relevant to individuals working within a French corporate setting, but that is now retained as a matter of tradition only.

Intensifying the effect of the traditional, but now largely irrelevant, coursework, the executive secretaryship curriculum suffers from bifurcation: the absence of any integration between the practical skills presented with the broader economic and political coursework. For Dewey (1916/1980), as noted earlier, the broad vision demanded that content from the sciences, social sciences, and humanities be integrated with preparation in more practical skills in a way that would facilitate critical understandings of the specific social and economic background against which individual economic endeavors were carried out:

The full intellectual and social meaning of a vocation would include instruction in the historic background of present conditions; training in science to give intelligence and initiative in dealing with material and agencies of production; and study of economics, civics, and politics, to bring the future worker into touch with the problems of the day. (328)

The approach taken in the executive secretaryship program, by contrast, quite effectively prevents students from making connections with "the scientific and social bases and bearings of their pursuits," leaving them doomed to the role of metaphorical "appendages to the machines they operate" (324). Most importantly, from Dewey's perspective, this approach fails to prepare students for the "power of readaptation to changing conditions so that future workers would not become blindly subject to a fate imposed upon them" (328). 


\section{From the Postcolonial to the Critical}

During his travels in China, Dewey (1921) noted the degree to which Britain's claims at fomenting the growth of democracy in its colonial possessions were a sham, agreeing with a British colleague that "the entire foreign policy of Downing Street was dictated by British financial interests" (4). Dewey's critique of colonialism was also informed by his professional and personal relationship with anti-colonialist scholar and activist Eric Williams, later the first Prime Minister of Trinidad and Tobago. In his landmark work, Capitalism and Slavery, Williams (1944) argued that, while it is commonplace to equate democracy with the growth of capitalism, the historic reality is far messier: slavery played a significant and radically underexamined part in the development of Britain's capitalist economy. In his introduction to Williams's later work on educational reform, Dewey (1946/1989) noted that the difficulty in achieving educational change such as Williams proposed for the colonized peoples of the Caribbean "is a heritage not only from the enslavement of the African and other peoples, but from the era of Colonialism that followed the industrial revolution" (308-309). As these examples suggest, Dewey's understanding of the tensions between capitalism and democracy anticipated a great deal of later critical thought-perspectives we now employ to move our analysis from the postcolonial to the critical.

Dewey (1916/1980) was adamantly opposed to the common practice of "merely trying to give a technical preparation for industries and professions as they now operate, much less by merely reproducing existing industrial conditions in the school" (325). This was because "any scheme for vocational education which takes its point of departure from the industrial régime that now exists, is likely to assume and to perpetuate its divisions and weaknesses, and thus to become an instrument in accomplishing the feudal dogma of social predestination" (328). In this, his insights presaged Althusser's (1971) analysis of the role of the Ideological State Apparatus (ISA) in perpetuating capitalist exploitation: the school teaches vocational skills "in forms which ensure subjection to the ruling ideology or the mastery of its 'practice"' (133).

In this regard, the executive secretaryship program has a clear focus upon preparing students for a highly authoritarian workplace through inculcation to its norms at the expense of preparation for critical inquiry and analysis, innovation, or creativity. Classroom pedagogy explicitly reflects the culture of global corporate enterprise, in which corporate strategy, identity, ideology, and particularly corporate ethics and rules are to be mastered-as opposed to the critical inquiry into these constructs we might imagine as a part of a Deweyan curriculum. Examples chosen to illustrate lessons in the existing curriculum are mainly those from job life: relationship between boss and employee, rules of hierarchy, ethics on workplace, honesty and respect towards co-workers, docility, and celerity at work. Through these, teachers show the manners or behavior of the workplace, playing the role of bosses, and sometimes acting as customers in need of service that has to be pro- 
vided by secretaries. The assessment through the national examination system also targets the same goal: to reflect the workplace ideology by measuring professional skills supposed to be in the contents of the curriculum.

Neoliberalism has had the effect of heightening this traditional formulation, often with the addition of state-level controls and assessments, such as state involvement in designing and assessing its system of public education explicitly in relation to the market sector. ${ }^{2}$ We see this in the articulation of students' learning as objective-centered, defined in terms of its economic importance for the broader society, and observable and measurable through standardized objective means-the national examination system. The assumption is that the more a school gets good results, the more it meets the curriculum goals. This vocational training program has a workplace vision in what concerns its social efficiency: adequacy in training to meet corporate needs. Thus, consciously or unconsciously, the training mechanism, run by teachers and administrators, is focused on the dominant economic demands, and is supposed to develop the basic skills needed by employers. Taken together, this explicit training of students for the workplace makes the vocational system what Rosentock and Steinberg (2007) have termed a "factory of workforce."

\section{FEMINIST CONSIDERATIONS}

The neo-colonial intensification of systems of authority and exploitation are particularly striking in the case of Togo's women. The hope of many working toward educational improvement for African women is that preparation for employment can become a way of eliminating poverty and furthering women's emancipation. And interestingly, in light of longstanding concerns about women's educational opportunity, enrollment figures for Togolese elementary schools show that $76 \%$ of students are females; however, the enrollment of girls falls off rapidly at the secondary and postsecondary levels (Kudaya). In post-baccalaureate vocational educational programs generally, there is a predominance of male students, and in engineering and industrial fields there are very few female students, if any:

Girls opt for short cycle courses in terms of professions in Togo and only 1.57\% go to the industrial sector. Also in certain schools in Togo there are only 3 [female] teachers for all the scientific disciplines. Even though there were $31 \%$ female technical teachers in Togo, there were none in engineering, plumbing, auto mechanics and electronics [in 1995]. (UNESCO 1995, 25)

Where women do "exist," in the first author's experience, they are in business and administrative fields. At least in part, this is due to efforts to encourage their insertion into vocational training, including a sort of "affirmative action" (also known as "positive discrimination," "reservation" or "employment equity") program designed to increase the representation of women. Access to post-secondary public vocational schools is through examination. In 1986, at the beginning of the 
executive secretaryship program, the entrance examination and admission decisions disregarded gender and the majority of students were male. A survey study conducted with employers in 1990, however, revealed that there was a demand for more females at the post of executive secretary than for males, which led to the decision to recruit and train more females in the program. To give an improved chance to female students, the numerus clausus ${ }^{3}$ is set with a majority of slots reserved for females in the program. These dispositions have directed many female students into vocational training in executive secretaryship, ${ }^{4}$ since it is supposed to give them the opportunity to earn a job and to live their own lives with less social pressure.

On the surface, the increased presence of women in programs such as executive secretaryship studies would seem to imply that the goal of female emancipation is being realized. We argue, though, that the situation is far more problematic-that the demand for women in these positions is derived from a Western phallocentric workplace culture that regards women as more "presentable" in customers' eyes and more obedient or manageable than males. Freeburg and Hall (2008) have observed a parallel process in both the US and in Europe, where, in the nineteenth century, $90 \%$ of clerical workers in business corporations were men. By the late 1800 s, however, women began to enter clerical occupations, and employers quickly came to consider women to be more docile and cheaper than men, and thus preferable.

A Western feminist perspective might suggest that the goal of any improved system of vocational education must be to allow Togo's women to compete on an equal footing with men-to be educated, in the context of this discussion, in vocational programs that will allow them to achieve both economic equality and personal agency. These goals are clearly incompatible with the direction of women toward positions that value submission and docility. The application of so-called "metropolitan" and first-world feminisms to the feminism of the developing world is deeply problematic, however: to assume some measure of intimacy and solidarity, especially in the right to speak for subaltern women, is to perpetuate colonial patterns through the underlying inequalities. As Jalalzai (2002) observed, this is a problem that even Spivak is not entirely successful at negotiating: across her various works, Spivak simultaneously argues that one must not regard the subaltern woman as an extension of one's self, but also asserts that if any authentic communication is to occur, one must still regard her without alterity (33-36).

In Togo, as in most African countries, current social roles still carry traditional norms. Boys are considered the heirs to the cultural heritage and the principal earners, while the women bear the responsibility for children's education and the household. Gendered differentiation of roles is a longstanding practice throughout Africa, although the traditional model was typically one of complementarity rather than of strict hierarchy. For example, while both sexes might work in farming or trade, the individual tasks may be sex-specific: men prepare the land for planting while women tend crops; women transport crops to market while men fell trees 
and cut brush, etc. Women were offered some measure of economic independence within this system through traditional crafts and trade in household products, but these were rendered largely obsolete by the imposition of colonial-era economic systems so that sexual differentiation was supplanted by economic discrimination (Sudarkasa 1982, 1986).

As Dube points out, the focus in the postcolonial era for many African nations has been upon reclaiming pre-colonial culture, implying a return to the model of complementarity that prevailed prior to colonization, rather than a turn toward a Western norm for feminine agency (217). She has also argued that African women in contemporary society must be understood to be doubly burdened by the combination of patriarchal structures with colonial/neocolonial structures. While men's efforts may be turned outward, women may just be focused upon their own survival and that of their children, leaving no time to turn their attention to larger dialogs or to speak for themselves (223-25). Summarizing Dube's argument, with the addition of Spivak's thought on female agency, we might say that the continuing inscription of identity as the Other-always in relation to the colonizer-even as it robs all Africans of indigenous tribal identity, further invigorates the colonial and patriarchal pressures upon women.

The much-touted practice of micro-lending has sought to address precisely this complex of issues, working to provide women with the means to gain a measure of economic security and personal agency through funding efforts related to their traditional societal roles. As Izugbara (2004) found in Nigeria, though, while these efforts do seem to effectively intervene in pressing issues of poverty for women and children, there is not convincing evidence that they actually lead to sustainable improvements, or especially toward improved social position and autonomy.

We must acknowledge here that we write as a Togolese male educated in Togo's French postcolonial system of education (the first author) and a White American woman whose postcolonial and feminist commitments cannot be disarticulated from her middle-class first-world life experience (the second author). Each of us is to some degree connected with Togolese women, through shared experiences and historical circumstances of oppression through colonialism (the first author) and patriarchy (the second author), yet neither of us can fully share the redoubled oppression noted by Dube. Our advocacy here, then, reflects to at least some degree a dilemma Spivak articulates: the lack of agency and voice for women in patriarchal and colonized settings, wherein others make decisions as to their welfare.

\section{Directions for Reform: Employing Deweyan Principles}

In Democracy and Education, there might at first appear to be a broad mandate for a singular and Westernized approach reform to Togo's system of educationand by extension to the situation of its women. Clearly, there are principles that Dewey (1916/1980) believed were broadly defensible; he was concerned with mak- 
ing "a critical estimate of the theories of knowing and moral development which were formulated in earlier social conditions, but which still operate, in societies nominally democratic, to hamper the adequate realization of the democratic ideal" (3) - surely the situation for Togo generally, and of the executive secretaryship program in particular. Dewey also argued that, while differing social groups had their own needs and standards, there were interests held in common. Further, those principles that allowed individual social groups to exist in relation to others within the larger global sphere were beneficial and ought to be favored in efforts toward improvement (89).

At the same time, however, Dewey's (1910/1978) appreciation for "particularity," understood as "the local and contingent characteristics of individual settings" (84-85), was integrated with an instrumentalism that demanded that individual cases be evaluated according to their own circumstances, rather than in relation to any universal values or standards. ${ }^{5}$ In this, we see a delicate balance between the local and particular and the larger system-between the needs and desires of individuals and small communities that must be met in response to one another and local conditions, while also attending to still larger systems. As such, judgments as to successes and failures would also be delicately balanced, and must consider local communities and also the degree to which consequences extend the local to larger social systems.

Keeping these principles in mind, we return to the case of Togo's women, not only for their own sake, but for the ways in which the tensions between local needs and practices and larger principles related to democratic life enlighten this discussion. Given the issues of agency that we identify for women, and the guidance provided by Dewey's attention to particularity, we present our preliminary thoughts primarily in relation to the work of an African woman, Dube. While Dube's work does not address vocational education explicitly, it does very definitely speak to Dewey's notion of vocation understood as the union between the ability to earn a living and a "conception of the calling of [wo]man in fulfilling [her or] his moral and intellectual destiny" (Dewey 1917/1980a, 151).

It is difficult to imagine how women's right to exercise agency-to take part, in Deweyan fashion, in deliberations as to the means that will support their future development-can truly be carried out in the absence of familiarity with the wider social realm. This aligns with Dube's opinion that what must be sought is a "model of free exchange, dialogue, of choosing and rejecting across cultures" (225). She offers as an example the experience of African within the context of the African Independent Churches (AICs). While clearly developed in relation to the influence of Christianity, the AICs have also selectively adopted and adapted elements of older indigenous practice. Of particular note, women play a strong and central role, exercising authority as healers, prophets, and founders and leaders of new churches. African women writers, as Dube points out, are similarly engaged 
in increasing exchange and communication across global and cultural barriers, taking part in discourses of resistance and liberation.

This process seems coherent with Said's advocacy, also; for him, "resistance, far from being merely a reaction to imperialism, is an alternative way of conceiving human history ... writing back to the metropolitan cultures, disrupting the European narratives of the Orient and Africa, replacing them with either a more playful or a more powerful new narrative style is a major component in the process" (26). Extending this line of thought, then, the essential first step would be for women to gain access to areas where such dialog and exchange can take place-a perspective that again would apply to Togo's vocational system.

When viewed from this perspective, current approaches to reform give rise to concern. As Breidlid (2009) has found, efforts at educational reform throughout Africa have been largely derived from Western ideas and approaches. The neglect of Indigenous Knowledge Systems (IKS), in his account, has privileged European epistemologies and created a dual system throughout society, where school-based learning is dominated by Western modes of thought, while traditional beliefs and practices continue to dominate home and community life. As one example of this pattern specific to Togo, the German approach to blending theoretical school-based education with hands-on experience at worksites was envisioned as an economically viable and effective way to increase the vocational preparation of larger numbers of youth. However, the German model encountered difficulties due to language and cultural barriers. School-based educators were perceived as interfering by workplace supervisors, and differences in language between the all-French school settings and the worksites, where local language tends to dominate, frustrated these efforts. Even more importantly, the individualistic and entrepreneurial aspects of these programs were at odds with the more collective focus of traditional societal structures (Kempner et al 1993).

As noted earlier, financing for many African efforts toward substantial educational reform has come through UNESCO, and attention is now focused upon a holistic approach to skills development for employability and citizenship in relation to economic and environmental sustainability. The idea is that, through placing an emphasis within skills training programs on developing a sense of values, ethics and attitudes, the learner will become prepared for self-reliance and responsible citizenship (UNESCO 2004). This developing sense of the larger context of vocational preparation at first seems well-aligned with much our Deweyan theorizing; however, a review of the action plan reveals a top-down approach through existing governmental entities, with little or no attention to the issues we have outlined above.

Even more problematically, from our perspective, is that the traditional goal through UNESCO's efforts has been to prepare young people and adults for the world of work by providing them with knowledge, skills and competencies that are aligned with existing social and economic structures-the very structures we have analyzed in terms of their manifestation of neo-colonialism. 
While UNESCO's overall goals - to improve individual and social welfare-are laudable and certainly much-needed, we argue that they must be augmented by deeper consideration of postcolonial concerns, and of adaptation to meet local needs and priorities. As Dewey (1916/1980) knew, too, these kinds of changes will not come easily:

This ideal has to contend not only with the inertia of existing educational traditions, but also with the opposition of those who are entrenched in command of the industrial machinery, and who realize that such an educational system if made general would threaten their ability to use others for their own ends. (328)

Given that UNESCO's funding derives from existing economic structures and seems likely to continue to reflect those interests, wide-scale reform that would truly reflect the scope of Dewey's democratic vision seems unfeasible, at least in the near term. At the same time, as we have hoped to demonstrate here, it is still possible to extract principles from his writings to assist individual educators and programs in making changes locally, to ensure that students in those programs have improved access to the kinds of opportunities for critical thought Dewey championed. Certainly, this must also, in Deweyan fashion, be accompanied by ongoing evaluation of the effects of decisions taken.

The larger hope would be that, ultimately, locally and regionally derived understandings would come to inform ongoing funding decisions for UNESCO and other international agencies. In other words, we suggest that incremental change may be the best hope to spur wider educational change to prepare students for a meaningful and democratizing life's work, and to reverse the older systems of formulaic training that simply reinforce and reproduce unjust and unsustainable systems.

\section{Notes}

1. From Macaulay's “Minute on Indian Education,” (1835), as cited in Spivak (1988).

2. See, for example, Apple (2000).

3. A Latin term used to indicate a maximum number of students required after an entrance examination-in other words, a quota.

4. Per the first author's records, in 1986-87, 1987-88, and 1988-89, the representation of women in the program was $24 \%, 38 \%$, and $32 \%$, respectively. It increased to $65 \%$ for $1989-90$ and $1990-91$, and since then has ranged from $68 \%$ to $96 \%$, with an average of $79 \%$.

5. The following is one of his clearest statements on the issue: "The chief characteristic trait of the pragmatic notion of reality is precisely that no theory of Reality in general, uberhaupt, is possible or needed. Pragmatism is content to take its stand with science; for science finds all such events to be subject-matter of description and inquiry" (Dewey 1917/1980b, 39).

\section{REFERENCES}

Abdallah, A., \& K. Amouzouvi. Poverty Profile and Vulnerability in Togo. Lomé, Togo: Ministry of Economics and Development (MED), 2007.

\section{E\&C Education and Culture}


Alexander, Thomas M. "Educating the Human Heart: Pluralism, Traditions and the Humanities." In The New Scholarship on Dewey. Edited by Jim Garrison. Boston: Kluwer, 1995. doi:10.1007/978-94-011-0071-7_7.

Althusser, Louis. "Ideology and Ideological State Apparatuses (Notes Toward an Investigation)." In Lenin and Philosophy and Other Essays. Translated by Ben Brewster. New York: Monthly Review Press, 1971.

Apple, Michael W. "Standards, markets, and curriculum." In Curriculum \& Consequence: Herbert M. Kliebard and the Promise of Schooling. Edited by Barry M. Franklin. New York: Teachers College Press, 2000.

Boutin, André. Formation et Développements. Paris, France: Casterman, 1983.

Breidlid, Anders. "Culture, Indigenous Knowledge Systems and Sustainable Development: A Critical View of Education in an African Context." International Journal of Educational Development 29 (2009): 140-48. doi:10.1016/j. ijedudev.2008.09.009.

Dewey, John. "Art as Experience." In John Dewey: The Later Works, 1925-1953, vol. 10. Edited by Jo Ann Boydston. Carbondale, IL: Southern Illinois University Press, 1934/1981.

- - - "Democracy and Education." In John Dewey: The Middle Works, 1899-1924, vol. 9. Edited by Jo Ann Boydston. Carbondale, IL: Southern Illinois University Press, 1916/1980.

- - . "Education and New Social Ideals." In John Dewey: The Later Works, 1925-1953, vol. 11. Edited by Jo Ann Boydston. Carbondale, IL: Southern Illinois University Press, 1936/1987.

- - . "Forward to Education in the British West Indies." In John Dewey: The Later Works, 1925-1953, vol. 15. Edited by Jo Ann Boydston. Carbondale, IL: Southern Illinois University Press, 1946/1989.

- - - John Dewey to James H. Tufts: 1921.02.23 (07207). In The Correspondence of John Dewey, 1871-1952, vol. 2: 1919-1939 (Electronic edition). InteLex Corporation, 1921.

- - - "The Modern Trend Toward Vocational Education in its Effect upon the Professional and Non-Professional Studies of the University." In John Dewey: The Middle Works, 1899-1924, vol. 10. Edited by Jo Ann Boydston. Carbondale, IL: Southern Illinois University Press, 1917/1980a.

- - - "The Need for a Recovery of Philosophy." In John Dewey: The Middle Works, 1899-1924, vol. 10. Edited by Jo Ann Boydston. Carbondale, IL: Southern Illinois University Press, 1917/1980b.

- - - "Science as Subject-Matter and as Method." In John Dewey: The Middle Works, 1899-1924, vol. 6. Edited by Jo Ann Boydston. Carbondale, IL: Southern Illinois University Press, 1910/1978.

Dube, Musa W. "Searching for the Lost Needle: Double Colonization \& Postcolonial African Feminisms." Studies in World Christianity 5 (1999), 213-28. 
Freeburg, Beth Winfrey and Marion Hall. Foundations of Workforce Education, 2nd ed. New York: Pearson Custom Publishing, 2008.

Granger, David A. John Dewey, Robert Pirsig, and the Art of Living. New York, Palgrave McMillan, 2006.

Hook, Sidney. "Introduction.” In John Dewey: The Middle Works, 1899-1924, vol. 9. Edited by Jo Ann Boydston. Carbondale, IL: Southern Illinois University Press, 1980.

Izugbara, C. Otutubikey. "Gendered Micro-Lending Schemes and Sustainable Women's Empowerment in Nigeria." Community Development Journal 39 (2004), 72-84. doi:10.1093/cdj/39.1.72.

Jalalzai, Zubeda. "Trading French and Postcolonial Feminisms: Spivak's Ethics of Exchange." Literature and Psychology 48 (2002), 33-36.

Kempner, Ken, Claudio de Moura Castro, and Daniel Bas. 1993. "Apprenticeship: The Perilous Journey from Germany to Togo." International Review of Education 39 (1993), 373-90. doi:10.1007/BF01261589.

Kudayah, P. A. Education Memorandum of Togo for the Millennium Development Goals. Lomé, Togo: Ministry of Economy and Finance, 2008.

McGrath, Simon. "Where to Now for Vocational Education and Training in Africa?" International Journal of Training Research 9 (2001), 35-48. doi:10.5172/ijtr.9.12.35 .

Nyame, Jean Adama and Yao Nuakey. 2003. "Le Systeme Educatif au Togo," Centre de Ressources Documentaires, 2003. http://doc-aea.aide-et-action.org.

Obanya, Pai. "Case Studies of Curriculum Innovations in Western Africa." International Review of Education 41 (1995), 315-36.

Rosenstock, Larry and Adria Steinberg. "Beyond the Shop: Reinventing Vocational Education." In Democratic Schools. Edited by Michael W. Apple and James A. Beane. Portsmouth, NH: Heinemann, 2007.

Said, Edward. Culture and Imperialism. New York: Vintage Books, 1993.

Seltzer-Kelly, Deborah, Sean J. Westwood, and David M. Peña-Guzman. “Deweyan Multicultural Democracy, Rortian Solidarity, and the Popular Arts: Krumping into Presence," Studies in Philosophy and Education 29 (2010), 441-57. doi:10.1007/s11217-010-9190-y.

Spivak, Gayatri Chakravorty. "Can the Subaltern Speak?" In Marxism and the Interpretation of Culture. Edited by Cary Nelson and Lawrence Grossberg. Urbana, IL: University of Illinois Press, 1988.

Sudarkasa, Niara. "Sex Roles, Education, and Development in Africa." Anthropology \& Education Quarterly 13 (1982), 279-89.

- - “ "The Status of Women in Indigenous African Societies." Feminist Studies 12 (1986), 91-103.

UNESCO. The Bonn Declaration on Learning for Work, Citizenship and Sustainability, 2004. http://www.unevoc.unesco.org/publications/pdf/ SD_BonnDeclaration_e.pdf. 
- - - "Special Project on Scientific, Technical and Vocational Education of Girls." In: Africa: Summary of 21 National Reports, 1995. www.unesco.org/education/ educprog/ste/pdf_files/girls/reports.pdf.

- - - Why and How Africa Should Invest in African Languages and Multilingual Education: An Evidence- and Practice-Based Policy Advocacy Brief, 2010. http:// unesdoc.unesco.org/images/0018/001886/188642e.pdf.

Williams, Eric. Capitalism and Slavery. Chapel Hill: The University of North Carolina Press, 1944.

Tairou Goura was a Fulbright grantee at Southern Illinois University, Carbondale where he received his $\mathrm{PhD}$ in Educational Administration.

E-mail: gouratairou@yahoo.com.

Deborah L. Seltzer-Kelly is Byron K. Trippett Assistant Professor in the Department of Education Studies at Wabash College.

E-mail: seltzerd@wabash.edu. 